University at Albany, State University of New York Scholars Archive

2003

\title{
Common Origins/"Different" Identities in Two Kaqchikel Maya Towns
}

Walter E. Little

University at Albany, State University of New York, wlittle@albany.edu

Follow this and additional works at: https://scholarsarchive.library.albany.edu/cas_anthro_scholar Part of the Folklore Commons, Latin American Studies Commons, and the Social and Cultural Anthropology Commons

\section{Recommended Citation}

Little, Walter E., "Common Origins/"Different" Identities in Two Kaqchikel Maya Towns" (2003). Anthropology Faculty Scholarship. 11 .

https://scholarsarchive.library.albany.edu/cas_anthro_scholar/11 


\title{
COMMON ORIGINS/ "DIFFERENT" IDENTITIES IN TWO KAQCHIKEL MAYA TOWNS ${ }^{1}$
}

\author{
Walter E. Little \\ Department of Anthropology, University at Albany, State University of New York, \\ Albany, NY 12222
}

Kaqchikel Maya residents of San Antonio Aguas Calientes and Santa Catarina Barahona (neighboring towns in Guatemala) tell the same origin story. This story is used to root historically their concepts of collective identity and community. However, residents in each town hold that those in the other town have no real claim to the story. Both towns can equally claim this origin story, but the debate between residents of these towns offers an opportunity to discuss how the meaning of place is related to the historical and ethnographic contexts of which that place's residents are part. By weighing the story and residents' explanations about why it is theirs against previous historical accounts, I show that Spanish colonialism, religious evangelism, economic competition, and development contributed to divisions between the towns and skewed their concepts of origin.

KaqChikel Maya REsidents of the neighboring towns of San Antonio Aguas Calientes and Santa Catarina Barahona, located in the Quinizilapa Valley roughly six kilometers from La Antigua, Guatemala (see Figure 1), tell the same origin story. The story, however, is not merely a chronicle of the past that gives time depth to Maya concepts of collective identity and place. Residents leave out documented ethnographic and historical details (see, e.g., Annis 1987; Brown 1998; INI 1948; Lutz 1994; Oria 1989), as they use it strategically to distinguish their respective town to development organizations and tourists. Members of each town assert that the story is solely their history and their property and contest the other's claims to it.

How Kaqchikeles from San Antonio and Santa Catarina use the story, not the content of the story, will be analyzed by taking into consideration Appadurai's $(1998,1996)$ theories about the production of locality in a transnational context and Watanabe's $(1990,1992)$ theories about maintenance of Mesoamerican communities. The fusion of these two theoretical perspectives can help explain why the story has social, economic, and political value for contemporary Kaqchikel Mayas in these towns.

In order to show why Kaqchikel Mayas use the story and why its use is contested by members of the two towns, I begin with local oral and scholarly historical perspectives. The value of the story will then be discussed in relation to the impact that religious missionization, international tourism, and economic development have had on San Antonio and Santa Catarina.

Journal of Anthropological Research, vol. 59, 2003

Copyright $(\odot$ by The University of New Mexico 


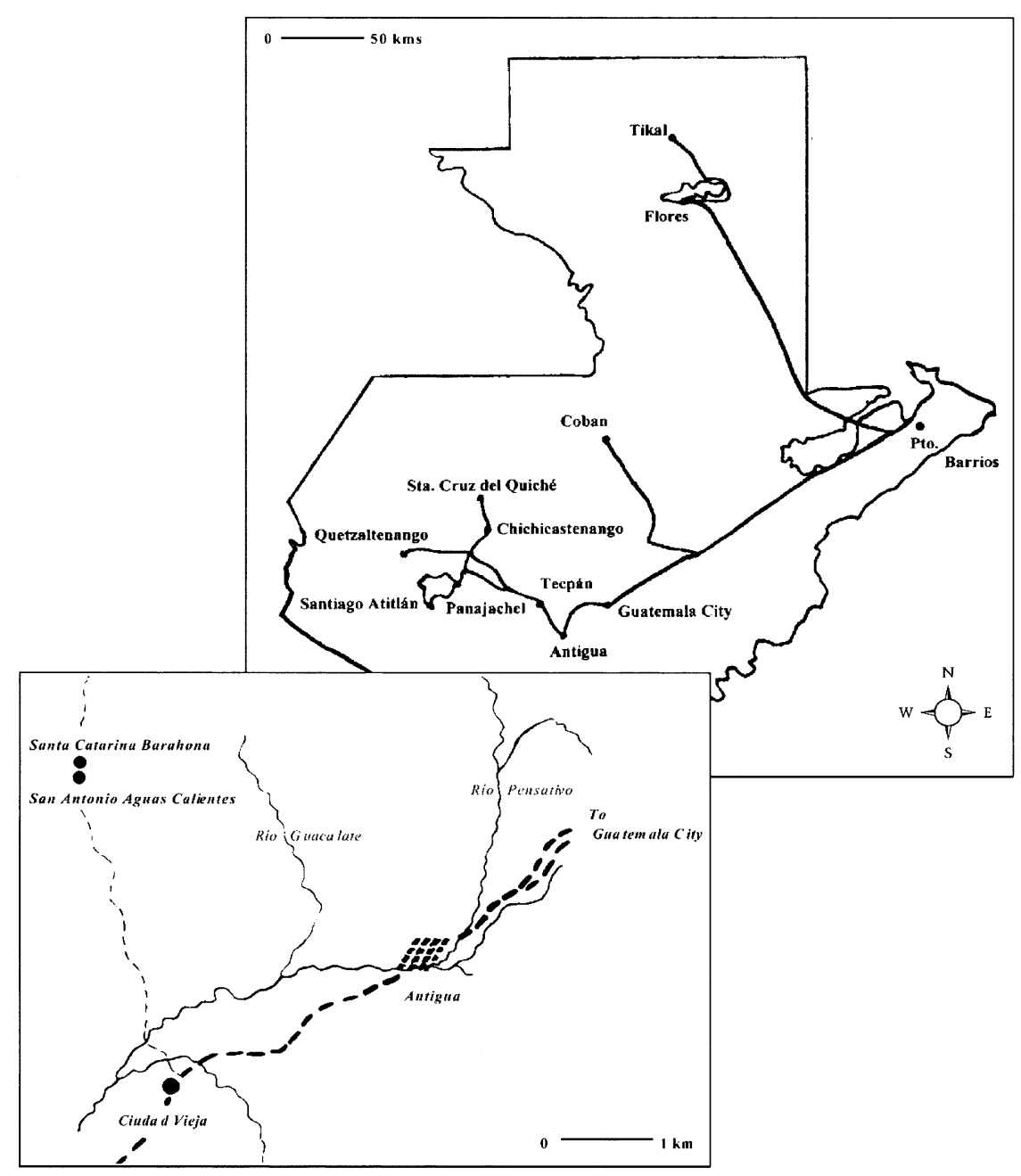

Figure 1. Location of Santa Catarina and San Antonio in Guatemala

The origin story being told by Kaqchikel Maya residents of San Antonio and Santa Catarina presents an interesting case study because it illustrates how Mayas continue to view their communities as meaningful places in an increasingly globalized world. Kaqchikel uses of the story to mark identity and place contrast with the thesis that global processes are weakening the links between people and place. However, their use of the story does illustrate how global forces can be instrumental in circumventing the state and in dividing local communities.

Consideration of Watanabe's theories of community and Appadurai's theories of locality together helps explain why missionization, tourism, and development are transnational forces that are producing new conceptualizations of place for Mayas from these towns. According to Watanabe (1992:11-17, 1990:184-85), 
Maya communities are the result of the ongoing activities of individuals living together over time within a delineated social and geographical space. For Watanabe (1992:12), community is located within "existential relations because ... the conjunction of place, people, and premise" helps show why people live together in communities. He defines premises "as the conventional strategies for surviving in that place" (Watanabe 1990:184). Premises that are shared by individuals are then used by members of the community to differentiate themselves from others.

Although Watanabe $(1992,1990)$ is concerned with the impact of the Guatemalan state and broader global economic and political forces, Appadurai (1996) focuses more on the ways that globalized communication, economics, and politics make it difficult for nation-states to control their populations and their territories. He holds that such global forces make "producing locality (as a structure of feeling, a property of social life, and an ideology of situated community) . . . increasingly a struggle" (Appadurai 1996:188-89). According to Appadurai, these forces are so great that people are not meaningfully linked to specific territories. To counteract these global processes, nation-states engage in various practices of delineating, naming, and regulating people within geographical spaces. Hence, nation-states attempt to define and control people and the places where they live in contradiction to the global movement of commodities, people, and ideas.

In the recent past, residents of both San Antonio and Santa Catarina claimed the origin story equally without controversy. I discuss why the story is important to them by reviewing the history of the region in relation to the contemporary ethnographic context. The story has become a restricted commodity-not the common sort-namely, one that gains value through exchange and takes on a social life as it is put into and taken out of circulation (Appadurai 1986; Marx 1970). Residents considered the story to be community property that is to reside within the community ${ }^{2}$. The story's value relates to the ways that residents use it to bring revenue into their respective communities. In particular, the story is a statement of the authenticity of the community. The story's exchange value emerges through the telling of it to government officials, agents of development projects, tourists, and even scholars such as Carey (2001) and myself. Instead of being an item or concept that is sold in the market, it is used as a "lure" to catch potential sources of money.

The story and other forms of performance in these towns have been commoditized (Little 2000) like the tourism performances that Cohen (1988) and MacCannell (1992) discuss, but unlike the handicrafts and arts that Graburn (1976) discusses. Appadurai (1986:47) explains that "tourist art constitutes a special commodity traffic, in which the group identities of producers are tokens for the status politics of consumers." To this explanation it is relevant to add (following the respective research by Cohen, MacCannell, Graburn) that performances for tourists are commodities. Kaqchikeles, however, tell this story for reasons beyond giving photo opportunities and selling a few trinkets to tourists. 


\section{LOCAL HISTORY}

Versions of the origin story are told by Kaqchikel Maya residents of San Antonio Aguas Calientes and Santa Catarina Barahona at birthday parties and weddings, in the milpa (maize field), in the tourism marketplace, while weaving, and during periods of relaxation. The story is a local history that people volunteered without solicitation. The version of the story included below was the first one that I heard. ${ }^{3}$ It was told by an individual who worked in tourism.

\section{The Kaqchikel Origin Story}

Ojer ojer kan, xojkoje' pa juyu'. Man wawe ta. [Long long ago we lived in the countryside, on the mountain, not here.] There was no town. Parents and children, families, our people, lived in the country. We planted maize and beans and chile. We hunted deer in the forest and crabs in the springs. For many years we lived this way, but each year we had more problems with the utiw [coyotes]. We were very scared of the utiw. They attacked our families and drove away the game. Times were very bad. Our people on the mountain countryside decided to unite, to move off the mountainside and live in the valley, where there was a lake. When we lived on the lake, we wove mats from the reeds that grew on the shore. We fished and farmed. There were no problems, until one year a disease came to the lake. Many people died. First the children and the old, but then others. The town became a graveyard. That town is where the cemetery is today. Because of the disease, we moved again, between the lake and the mountain, which is where we live today. The lake was drained. The fish died. The reeds died. We still farm, but there are no fish. Most people stopped weaving mats, especially the men, but some women still do. They have to buy reeds now. Because there was no lake, no fish, no reeds, it was then that the women really learned how to weave huipiles [handwoven blouses] and why our town is famous today. ( $\mathrm{T}$. Chavez, San Antonio Aguas Calientes, March 17, 1997)

Carey (2001:70-81), by contrast, collected different and more detailed versions of the origin story, primarily from farmers and teachers who focus just on origins, rather than a condensed history of the town. Carey discusses the story, as an oral history, alongside official written history and the context of debates over land, water, and money that have existed between the two towns since at least the Spanish colonial period. Although residents may have competed for these resources since the early sixteenth century, I will argue that the importance of the origin story in establishing one town or the other as first and prior to Spanish conquest and that its telling - while Carey and I conducted our individual research projects-relate to contemporary economic struggles over development projects and tourism money.

The story briefly explains changes in the location of the town and shifts in economic activities over a period of several hundred years. It noticeably lacks any 
mention of the Spanish colonial period, tourism, or evangelism, which have been central to historical and anthropological studies of these two towns. Kaqchikeles of both towns are not naive about the official history of the region or that since the Spanish colonial period they have been integrated into regional and world economies. They have experienced religious conversion by Catholic priests beginning in the sixteenth century and more recently during the twentieth century by Protestant missionaries. They are equally aware that they have been the objects of regional and international tourism since the early 1900 s and that the women, seated at their backstrap looms, along with their weaving have become symbols for Guatemalan tourism and indeed for the nation itself (Annis 1987; Brown 1998).

When individuals from one town learned that people in the other town tell the same story, their immediate responses tended to be that the others were liars, thieves, mistaken about the history of the region, or poorly educated. However, some commented in more complex ways, which relate to the Spanish colonial period, religious change, and tourism:

1. According to Tomás from San Antonio, both towns were the same. "Sure, the Spaniards had split the people into two municipalities, but neither was truly different until the Protestant missionaries came in the early 1900s. After this time, Santa Catarina truly become different, and many people gave up costumbre" (the practice of traditions that help maintain community order; Warren 1989).

2. Antonio explained that his town of Santa Catarina was "the original town. Spaniards brought outsiders to make San Antonio Aguas Calientes to work on the plantations. They adopted the dress, language, and costumes of the people from Santa Catarina Barahona. The towns' names were imposed, but the residents of Santa Catarina are descendants of the original inhabitants."

3. María from San Antonio contends that her town was the "first town in the valley. Spaniards brought in laborers to work the finca [estate] of Sancho Barahona. They then adopted the language and other costumes of San Antonio, such as weaving. Residents of Santa Catarina have always followed San Antonio's innovations because they don't know their origins."

4. And according to Irene from Santa Catarina Barahona, "San Antonio and Santa Catarina have always been two different towns. We tell the story of our town, because it is ours. It shows where we come from. People in San Antonio have forgotten their history because of the changes brought by the mo'soi', ${ }^{4}$ like tourism and evangelism."

Until recently, the story was used by residents of both towns to distinguish themselves from others, but it is now being used to differentiate themselves from one another. The previous examples are significant because residents use the same types of explanations to claim the story. The second and third examples are even mirror images of each other. These types of explanations did not occur until the 
mid-1990s. The examples demonstrate that the residents of each town think about how they have been subjected to Spanish conquistadores and religious missionaries, as well as to the forcible consolidation of indigenous peoples in the colonial period ${ }^{5}$ and to tourism and development projects since the beginning of the twentieth century. In years prior to 1997 and during my more recent trips (JuneJuly 2000 and 2001), some residents still spoke of the origin story, their language (Kaqchikel), their food traditions, and their clothing in regional terms. As a friend lamented one day, "It is a shame that San Lorenzo and Santiago Zamora and San Miguel [other nearby Kaqchikel towns in same valley] have become Ladino towns. We used to be alike, have the same costumbre." Other older residents of San Antonio and Santa Catarina echoed his sentiments and blamed this negative (in their opinions) change on a poor economy, political pressure from the state, and international development agencies, which "caused them to lose their way and their traditions."

\section{ON WRITTEN HISTORICAL PERSPECTIVES}

Comparing written history to Kaqchikel oral understandings of history helps illustrate how residents position themselves in relation to the Guatemalan nationstate. These understandings, as well as those expressed by Kaqchikeles in subsequent sections, help refine Appadurai's (1996) theories, which show how the nation-state is instrumental in defining its citizens and territory in contrast to global processes, by demonstrating how some subjects of the nation-state, as a result of global processes, interpret and redefine their identities and communities in contrast to the nation-state. ${ }^{6}$

The origin story chronicles at least five hundred years of history. It begins with an indiscriminate date prior to Spanish conquest in 1524 when Kaqchikeles lived in a wild rural setting. It ignores the Spanish conquest, but certainly the struggles with the utiw could possibly be interpreted as Spanish conquest and control of the region. While is difficult to place a date on the time the town was organized, the contamination of the nearby lake and ensuing sickness and death occurred in a 1927 outbreak of malaria, after which the lake was drained (see Carey 2001:12935). Beginning in the 1930s, San Antonio and Santa Catarina weaving began to be recognized by the Guatemalan government under Dictator Jorge Ubico (19311944) and by international tourists. Handwoven textiles are of continuing economic importance to the residents of both towns (Little 2001, 2000). Notably, the story leaves out details commonly known by residents of both towns about the Spanish colonial period, independence from Spain in 1821, liberal reforms beginning in 1871, the CIA-backed overthrow of the Arbenz government in 1954, and the intense violence the Guatemalan government wreaked largely on the indigenous population in the 1980s. Instead, the story presents to development workers, tourists, and anthropologists a pristine Kaqchikel community that has not been influenced by Spanish colonial or Guatemalan national governments.

According to documents from the Spanish colonial period, both towns were milpas $^{7}$ founded around 1530 by Spaniards Juan de Cháves and Sancho de 
Barahona in order to provide food and labor for Antigua, as well as income for the señores (lords) of the milpas (Annis 1987:16; Lutz 1994:27; Lutz and Dakin 1996). While it is possible to find pottery sherds and obsidian blades suggesting that the valley had been settled prior to Spanish conquest, Lutz (personal communication, November 9, 2001) indicates that although the Quinizilapa region was settled before Spanish conquest in 1524, there is currently no evidence in the archaeological, ethnohistorical, or historical record that connects the contemporary or colonial populations of San Antonio or Santa Catarina to the preconquest population. Various residents from these towns, however, have pieces of pre-Columbian pottery and obsidian blades in their homes. They feel that these artifacts demonstrate that their ancestors were living in the valley prior to Spanish conquest. Often, upon my first visit to a home, I would be guided to the family altar and shown these items. Carey (2001:74-75) likewise notes the contradiction between Kaqchikel origin beliefs, which contend they are direct descendants of the preconquest population, and the historical record, suggesting that such opinions are guided by "a strong sense of pride in their origins" and "identification outside of the Spanish dominion."

Lutz (1994:15 and personal communication, September 11, 2002) explains that during the early colonial period, indigenous communities were torn apart and their inhabitants in some cases were enslaved and forced into new settlements by their Spanish masters. Indian slaves in the towns surrounding Antigua were drawn from a variety of indigenous populations that spoke distinct languages, making the region linguistically and culturally diverse. In Guatemala, indigenous slavery ended around 1550 .

While no document has been found describing the population of San Antonio, the residents of Santa Catarina Barahona are described in a letter to the Spanish Audiencia Real in 1567. The town was comprised of speakers of Q'eqchi' (Alta Verapaz), K'iche' (Utatlán), Tz'utujil (Atitlán), Chontal (Tabasco or Oaxaca), and Pipil (Pacific coast of Guatemala) (Annis 1987:16; Lutz 1994: n. 54, 260). This linguistic diversity was common of the milpas surrounding Antigua (Lutz 1994:15). Despite the linguistic heterogeneity of San Antonio and Santa Catarina, Kaqchikel, not Spanish, became the lingua franca, in part because of the limited contact their inhabitants had with Spanish speakers (Annis 1987:16-17). Among themselves, residents agreed that the original language of the area was Kaqchikel. However, when I pointed out the historical facts, Kaqchikeles said that the researchers had to be mistaken. They did not doubt that other groups had been brought into the valley, but they questioned the lack of Kaqchikel presence. They said that the documents probably listed who was brought into the region, not who was already there. After all, they argued, how could Kaqchikel become the dominant language if there were no Kaqchikel speakers originally present. They said that it was because of their "ancestors that new indigenous groups learned speak to Kaqchikel and adopt the customs of the valley." Lutz (personal communication, December 16, 2002) notes that it is possible that Kaqchikel were in the Quinizilapa Valley when the milpas were founded in the 1520s. However, the Spanish had not yet crushed the Kaqchikel rebellion and large numbers of 
Kaqchikel were in hiding, although some had been pacified and "reduced" to settlements.

It is not my intention to point out that the historical research is wrong or that Kaqchikeles are mistaken about their origins. Instead, it is to emphasize that place and a continuous connection to that place are significant to the residents of these two towns. As Watanabe (1990:184) emphasizes, “"community' in the Mayan highlands ... begins with two irreducible realities: first, 'place' as a physical locale with a given populace and resources; and second, 'premises'." For people of both towns, place is central to the construction of their communities; it is constantly reconstituted through daily existential practices, which include telling oral histories (see Carey 2001). Kaqchikeles hold that it is a combination of descent and continued interaction and participation in one's town that makes one a member of the community. Hence, true members of the community are those who are born and raised in the locale of San Antonio or Santa Catarina, trace their ancestry to the founding of their town, and spend their lives participating in the community and contending with changing economic and political forces, such as colonialism, religious missionization, and international tourism. For example, a female handicrafts vendor in Antigua is married to a man from Tecpán. Although she was born in San Antonio, neither she nor her vendor friends from San Antonio consider her a part of that community, because she interacts with San Antonio only as a visitor. ${ }^{8}$ Now the couple lives in Ciudad Vieja, another non-Maya town outside of Antigua.

Historical stories and the telling of those stories help Kaqchikeles constitute self in relation to the geographic and ideological spaces of their respective towns. The story serves as proof of origin and community-specific knowledge, which helps them anchor their collective identities and acts as both social and, indirectly, economic capital. Hence, it gets told at family and community gatherings, such as weddings and festivals, especially now when there are non-Mayas present who can help them economically.

As the historical data suggest, both towns were constituted by an amalgam of people from various regions of Guatemala and Mexico. However, no one today can distinguish among those living in San Antonio or Santa Catarina who were originally from Mexico or elsewhere in Guatemala. There are few traces of other Maya languages present. Furthermore, the two towns have been intertwined socially and economically for as long as residents can remember. Farmers of one town have land within the municipality of the other. Workers of one town provide labor or services to the other. Protestant residents from San Antonio attend church in Santa Catarina, just as those from Santa Catarina attend Protestant services in San Antonio. People from each town attend the other town's celebrations honoring their respective saints. Antoneco marriages to Catarinecos (and vice versa) are common. Residents recognize the interconnectedness of the two towns, historically, socially, and economically. The controversy over who can claim and use the origin story relates to other factors, not based on heredity or continued residency, that have promoted the emergence of new ethnic divisions. 


\section{RELIGION, TOURISM, AND DEVELOPMENT}

Although the Spanish colonial period provided some of the bases for reconfiguring the identity concepts of San Antonio and Santa Catarina residents, new ethnic divisions can be attributed more significantly to a recent combination of evangelism by Protestant missionaries, the growth of tourism, and the projects of economic development agencies. The changes precipitated by these developments have led to new strategic and tactical uses of identity by Kaqchikeles, in which the origin story is used to help them gain economic, political, and social opportunities.

\section{Religion}

One of the first Protestant mission schools in indigenous Guatemala was located on the border between San Antonio and Santa Catarina in 1874 (Brown 1998). The Central American Mission-a Protestant missionary group from the United States-established a permanent medical clinic in San Antonio in 1909 (Garrard-Burnett 1998:35), and a member thereof translated the Bible into Kaqchikel from 1919 to 1929 (Garrard-Burnett 1998:53; Stoll 1982:33). Today, Protestant churches in both towns are firmly entrenched, but there are few divisions between Catholics and Protestants. Many Catholics employ economic strategies similar to those used by successful Protestants (per Annis 1987), such as growing commercial crops, no longer contributing much or any money into the cofradias (lay Catholic religious orders that take care of the church and saints), and selling textiles directly to tourists. The Catholic church also now imposes fewer obligations on its congregation than it previously did. For instance, cofradia participation is not mandatory. While both Catholics and Protestants still feel that the others are spiritually misguided, several families have both Catholic and Protestant members.

Although the popular belief is that one gives up Maya cultural practices with conversion to Protestantism, the majority of Protestants who sell artisan products to tourists have chosen to maintain their Kaqchikel language and various other traditions, such as weaving for personal and family uses, the preparation of foods such as $x a q q^{\prime}$ 'utu' $n$ (sauce made from toasted chile peppers, tomatoes, and onions), to' $m$ (maize dough stuffed with black beans), and ichaj (a generic name for various dishes made with greens), and planting milpa, all of which they say are key to being a Kaqchikel person from San Antonio or Santa Catarina. It is true that today few Protestants cultivate anything larger than a small, garden-size maize patch, but growing numbers of Catholics are doing this too. This development has less to do with religion than with the lack of available agricultural land in relation to population, the growth of export agricultural crops (primarily flowers in this region of Guatemala), and the benefits of better wages in factory work and tourism.

Although planting maize is in decline, weaving-especially of tourism items-remains an important activity among women of both towns. One weaving practice - production of the ceremonial $s u^{\prime} t,{ }^{9}$ a rectangular cloth a bride gives her mother-in-law on her wedding day-is maintained by Protestants and Catholics 
alike. These gift su't are elaborately brocaded and can take the weaver up to one year to make. Unlike the huipil-also made by both Catholic and Protestant women-which Annis (1987:109) argues has different meanings for Catholics and Protestants, ${ }^{10}$ the $s u$ ' $t$ is used to link the young bride to her husband's family and to the community at large, regardless of religious affiliation. One Protestant bride labored for over one year weaving the su't she gave to her mother-in-law, who is also Protestant. As she presented the su't, she said humbly in Kaqchikel, "Please forgive me for not weaving a su't as beautiful as you deserve. I will understand if you don't won't wear it." As her mother-in-law unfolded it, she wept over the su't's beauty and craftsmanship. When she held it up for all to see, the wedding guestsProtestants and Catholics-were surprised by the quality of the workmanship. Those near me said, "That is a good daughter-in-law. She honors her mother-inlaw." After the su't was presented, we walked from San Antonio to the Ebenezer Protestant Church in Santa Catarina.

One might assume that the shrinking gaps in ideological and economic practices between Protestants and Catholics (Little 2001) would lead to more unified senses of ethnic identity. Instead, some Catholics in San Antonio hold that Santa Catarina is a Protestant stronghold because the residents there were easily converted. Similar comments by Catholics in Santa Catarina about Protestants in San Antonio were also made. In general, Catholics felt that the Protestants were a little less Kaqchikel than Catholics because they had converted. Protestants in both towns, however, claimed that religion had nothing to do with their Kaqchikel or community identity. Rather, they were-like Catholics-true descendants of the original inhabitants and real Kaqchikeles because they also maintain Kaqchikel cultural practices.

Catholics and Protestants in both towns try to identify religion as a way of demonstrating differences between residents in each respective town, but they have a difficult time showing that religion has split the two towns or that evangelism in one indicates that that town was not the original Kaqchikel town in the Quinizilapa Valley. Whereas membership in the Catholic church and participation in various Catholic orders and activities once served to unite residents, religion is now a poor marker of ethnic identity. The introduction of Protestantism in both towns, however, has contributed to the uncertainty of who can rightfully tell the origin story. Even though religious changes have contributed to divisions within the two towns and are used by segments of each town to make divisions between towns, they do not clearly illustrate why Antonecos and Catarinecos referred to themselves as members of different ethnic groups when debating which town lays the greatest claim to the origin story. To get at those reasons, it is necessary to look at the impacts of tourism and development.

\section{Tourism}

San Antonio Aguas Calientes has been a tourism site since the early 1900s. However, it was not until the 1930s, with the creation of what is now the largest tour company in Guatemala-Clark Tours - and the promotion of Maya life as a tourism attraction by Ubico (Guatemalan dictator from 1912-1944), that tourism 
began to have an economic impact on the town (Little 2001). From that time on, it has been one of the most mentioned places in guide books and one of the more frequently visited Maya towns in Guatemala. In contrast, Santa Catarina is rarely mentioned. Responding to the growth of tourism, residents of San Antonio and Santa Catarina began weaving items for sale to tourists. Most often families work together, with men, women, and children taking turns weaving, sewing, and selling. Those who are particularly skilled at one of these activities may dedicate most of their time to it. Very few people in either town are old enough to remember when tourists did not visit. Tourism is so much a part of life that some women explained that they began selling to tourists when they were still in their mother's womb.

The competition for tourists' money is steep among residents of both towns. A used huipil can sell for up to $\$ 200$, if it is made of high-quality cotton and silk. If it is an antique, it is worth much more. This is an especially lucrative item for the vendor if she is tired of the huipil. Huipiles and other woven products, such as su't, provide two types of wealth: one type serves as capital for women's connections to the community; the other type serves as monetary capital. When the social/ community capital decreases because the item is out of style, damaged, or faded, it can be converted into money in the tourism marketplace. New huipiles are rarely sold to tourists, partially because tourists tend not to pay the local prices these huipiles command, which can be as high as $\$ 600$. Many weavers would also like to see their handiwork live in the community for a period of time before being sold.

Because of its high profile in guidebooks and the promotional materials of the Guatemalan government and major tour companies, San Antonio Aguas Calientes has reaped the greatest benefits from tourism over the years. It is the place most recommended for tourists to buy handmade Mayan textiles. Santa Catarina Barahona, by contrast, is not described as a place to purchase textiles. In the Rough Guide (Whatmore and Eltringham 1990), tourists are encouraged to visit Santa Catarina's municipal swimming pool but not to buy textiles or experience "Indian" life, as they are to be found in San Antonio. Despite the lack of promotion, Catarinecos have capitalized on tourism by saying that they are from San Antonio. In recent years, they maintain that it has become difficult to make a living in tourism. In part this is because tourists are more careful to buy items made by weavers from San Antonio, which they consider to be the town that produces authentic brocaded weaving. Tour companies and guides even steer tourists toward particular San Antonio weavers and vendors, such as the shops of the Pérez family, Kaqchikel Protestants. To make matters even more difficult for weavers, many tourists are suspicious about the authenticity of woven products. They fear that the items may not be handmade by Maya women.

To counteract these trends, Catarinecos have begun to promote Santa Catarina as an authentic Maya town. As a preamble to asking me to distribute flyers at places in Antigua that are frequented by tourists, Mayor Hernandez told me the origin story. The flyers invite tourists to "come know Santa Catarina's Typical Clothes, hand-made by the Women of the municipality." Trying to appeal to all types of 
tourists, the flyer also plays on colonial history (the "only colonial fountain in the department") and nature ("you'll return enchanted by the natural beauty"). He and others encouraged me to spread the word about Santa Catarina, to stress that it is the town where brocaded weaving originated and that it has contributed the most weaving innovations, not San Antonio. In both towns, female vendors in finelooking huipiles and seated at looms can be seen by tourists, which further helps demonstrate that the cloth is handmade and that Mayas are making it. Mayor Hernandez said, "Women here don't weave because of tourism. They weave for their families and because of tradition. Our history [the origin story] helps remind us, our children, and others, like you, that weaving is very important and has always been here."

Tourist literature, tour companies, and guides link Mayas to particular languages, traditions, religious practices, and clothing that are located in particular places. In the case of San Antonio Aguas Calientes and Santa Catarina Barahona, however, it is difficult for tourists and guides to distinguish differences between the two towns ${ }^{11}$ because so many cultural traits are shared. Guides sometimes solve this difficulty by assigning authenticity to San Antonio, while disregarding Santa Catarina. To confound matters, touristic association of San Antonio as a Maya place was reduced to one family. When the Pérez family secured exclusive deals with Guatemala's largest tour companies, Clark Tours and Kim' Arrim, it was also the only family endorsed by INGUAT, the National Institute of Guatemalan Tourism. This did not change until early January 2000, when Catholic San Antonio plaza vendors, with the aid of the Protestant mayor, convinced INGUAT to endorse the new artisan marketplace. Likewise, Santa Catarina's mayor and weavers built a marketplace on the plaza and also tried to get INGUAT endorsement, but they were not successful.

Maya vendors try to capitalize economically on tourism by using the knowledge that touristic discourses divide San Antonio and Santa Catarina along ethnic lines. Antonecos may use their favored position as additional proof that they are the original inhabitants, but more often they use it to position themselves for economic gain, exploiting tourists' and guides' concepts of who and what is Maya. Catarinecos, on the other hand, have to work against touristic discourse. They take two approaches. The more common is to pose as someone from San Antonio. Few tourists or guides are able to distinguish between the residents of the two towns. In fact, about the only people who can tell Antonecos apart from Catarinecos are Antonecos and Catarinecos themselves. The other approach is for Catarinecos to resignify and assign Maya culture to themselves. The origin story is significant to Catarinecos in this context because they play on tourists' and guides' concepts of history and tradition to reestablish what is original. They reason that if visitors learned who the "true" residents are, Santa Catarina would be included as a tourist destination. By claiming exclusive rights to the story, they attempt to delegitimatize Antoneco claims to authenticity. This makes the origin story an important point of debate for Antoneco and Catarineco ethnic identity as Mayas to both the Guatemalan nation-state and to transnational tourists. Indeed, in three separate cases, vendors from Santa Catarina and San Antonio, who were 
attempting to obtain INGUAT endorsement, used the origin story to show they were "authentic Indigenas." ${ }_{12}$ Within touristic spaces, the origin story becomes one of several ways in which residents from both towns authenticate themselves.

\section{Development}

This discussion of development relates primarily to how Antonecos and Catarinecos talked about development projects and their personal relationships to previous and current projects in Guatemala. A number of Kaqchikeles from both towns worked for Guatemalan governmental, nongovernmental, and religious development organizations, which dealt with Maya education and language promotion, community health programs, handicrafts training programs, and refugee repatriation in other departments. Most residents of San Antonio and Santa Catarina had some prior personal experience as recipients of development projects within their respective town.

The frequency with which development projects enter conversations suggests that residents of both towns have been profoundly affected by them. Annis comments (1987:44) that San Antonio "has attracted more than its share of postsixties development projects." When Annis did his research, San Antonio was frequently selected for rural development projects through USAID (U.S. Agency for International Development). Antonecos and Catarinecos were eligible for lowinterest loans through BANDESA (the National Agricultural Development Bank) for small agricultural projects and for cash to pay hired laborers until the harvest was sold. Through CORFINA (Corporación Financiera Nacional), which also provided loans after the 1976 earthquake, Catarinecos and Antonecos set up tiendas (shops) to sell handicrafts to tourists (Annis 1987:44-45, 148, 158, and 160).

Today, however, development projects within San Antonio and Santa Catarina are on the decline. This is due to factors related to political shifts within Guatemala. Compared with many other areas of Guatemala, San Antonio and Santa Catalina suffered very little violence during the thirty-five-year civil war. ${ }^{13}$ No families in either town are listed on the refugee rosters (FNUAP 1997). Both towns have a higher level of education and more basic services, such as electricity and running water, than most other areas of Guatemala (INE 1996). For instance, the literacy rates for persons aged fifteen years and older in San Antonio and Santa Catarina are 90 percent and 88.6 percent, respectively. In San Antonio Palopó, a comparably sized Kaqchikel-speaking town located on Lake Atitlán, also near a major tourist town, Panajachel, the literacy rate is 31.9 percent.

Antonecos and Catarinecos are well aware of these differences. This does not mean that they do not want to attract future projects to bring money into their communities. Vendors from both towns commonly felt that working for a development agency was far more prestigious than selling to tourists or farming. Several parents proudly pointed this out when speaking of their children's actual or potential employment. Some young Kaqchikel men and women choose university programs in international relations, social work, and business management with hope of getting work in development agencies. 
When Antonecos and Catarinecos reflected on their experiences with development agencies, divisions between the two towns emerged. They felt that money was targeted at communities, not at individuals or groups with special needs. Getting funds for agricultural projects, streets, schools, or healthcare services depended on the ways in which individuals represented their town. In other words, how a town markets itself to development agency officials improves its chances to get funds. It was feared-especially by those in the smaller Santa Catarina - that the other town would get all the money for projects.

The mayors and other city officials also used the origin story to convince me to dedicate some of my research money and time towards projects of their choosing in their respective town. They did not try to enlist my help by explaining their neediness, but argued that development money was needed to help their town maintain its cultural and historical integrity. Each mayor held that money from development projects strengthened his community by improving services and employment prospects, since the maintenance of traditional cultural practicessuch as weaving and titular festivals-was expensive. Each mayor explained that without sufficient funds, his townspeople would have to use cheap substitutions or cut out some important community activities. Each reasoned that the maintenance of tradition was in the interest of the national government, since Kaqchikel Maya weavers are featured in various tourism and development brochures that are used to attract foreign money.

As in the case of sales to tourists, vendors from each town felt that they were in competition for limited economic resources. Getting those resources meant trying to attract development agencies to one's own town by demonstrating Indianness or Mayaness and tradition to those providing aid. With people from both towns using the same strategies and telling the same origin story, boundaries are not clear. To them, funds appeared to be allocated according to which community was the more "Maya" or "Indian."

\section{DISCUSSION: LIVING IN THE PLACE}

Living in San Antonio Aguas Calientes and Santa Catarina today means contending with missionaries, tourists, and development projects, which are part of both Guatemalan state policies and international organizations, each in turn with its own-sometimes contrary-objectives. These factors are woven into and became part of daily Antoneco and Catarineco life. This situation has led to new strategies and tactics for economic and social survival in these towns.

The origin story in some contexts, such as dealing with INGUAT, is used strategically, whereby residents hope to reproduce their respective towns for tourism with particular "ways of operating" (see de Certeau 1984). They plan how the story can be used in conjunction with weaving and cooking demonstrations, as well as handicrafts sales. In both towns, weavers and vendors worked with their respective mayors to construct handicraft marketplaces, where they tell the story or make reference to elements thereof. It was believed that the combination of weaving, story, and handicraft would 
make it clear to outsiders that their respective town was unique.

With regard to tourists, anthropologists, and development workers visiting these towns, the story takes on a tactical dimension, wherein it will be evoked by Antonecos and Catarinecos if it can be used to improve their economic or social positions. I believe the reason that it was volunteered to me so often had to do with the position of power and influence that the residents believed I might have, or would have in the future. By using the story to represent themselves as historically rooted Mayas, who actively maintain cultural traditions, they sought to convince me of their authenticity and value as research subjects, in order to get money and services. Those who understood that I was a student invited me to participate in various economic activities and collaborative projects, including writing popular books and producing videos, in anticipation of my future successes.

When the origin story is strategically pitched to development agencies or INGUAT, the people are making calculations of power relations (de Certeau 1984:35) that involve national and international entities. With regard to tourists, missionaries, and anthropologists, the story takes on a tactical dimension because the power relations have reconfigured the places of San Antonio and Santa Catarina. They are in "the space of the other" in these situations (de Certeau 1984:35-36) because tour companies, Protestant churches, and the Guatemalan state have incorporated the towns into touristic, religious, and state apparatuses that sometimes have ways of conceiving of and representing Mayas, of changing them ideologically and socially, and of maintaining order that are contrary to those that the Mayas have for themselves.

"Culture" is now conceived of as a thing of economic value for Kaqchikeles of both towns because that is what interests tourists, the government, and development agencies. However, since the "culture" tourists and others seek is perceived by Antonecos and Catarinecos as residing in specific towns-not in regions or groups of towns-they labor to promote their regional "culture" as town-centric. The struggle between the two towns over the origin story reflects one of many instances where their common "culture" is being divided and reinscribed into a more narrowly defined social place.

It is important to note that no one felt restricted by the changes brought by religious missions, tourism, and development agencies. To varying degrees, they embraced them as a ways of expanding social, economic, and ideological choices. While residents from both towns argued, sometimes using the origin story, the importance of maintaining traditions, no one objected to increasing their cultural repertoire. They are not just being made by these forces of change but are actively involved in their own production by engaging those forces.

Tourism agents and tourists and development organizations and workers have contributed to new configurations of identity within San Antonio and Santa Catarina, which have led to the problems that arise when persons within the same place compete over resources. Appadurai (1998:226) argues that "there is a growing sense of radical uncertainty about people, situations, events, norms, and even cosmologies" related to an increase in identities available. This creates new ethnic divisions, which are partly products of state policies and globalization, that 
make it increasingly more difficult for people to identify members of their "own" group and enemies posing as members of their own group.

While the residents of San Antonio and Santa Catarina are not involved in the types of volatile and violent political situations that Appadurai (1998) describes, their inclusion and participation in state policies and globalization have altered their roles and self-representation with regard to their communities. In turn, these alterations have contributed to changes in the ways that residents conceive of their communities. As Antonecos and Catarinecos try to keep their towns specifically Maya places in changing economic, political, and social contexts that emerge through their collective "premises" (see Watanabe 1990:184), it is possible to understand how producing locality "is a struggle" (see Appadurai 1996:189) for them. Not only subjected by the ways in which their towns are described and conceived of by the Guatemalan state and international religious, tourism, and development organizations, they are, in a sense, deterritorialized because they have been subsumed by national and global political, economic, and representational forces. This is not to argue that the actual physical place is not still important. The townspeople's tactics and strategies of using the origin story to get money and other resources reveal the dual processes of making community/place and the disassociation of community/identity from physical places by global processes about which Watanabe (1992) and Appadurai (1996) respectively theorize.

One of the ways in which Antonecos and Catarinecos have responded to representations in the global media has been to use the origin story as a way to anchor themselves territorially and ideologically. Because missionary, tourism, and development practices have tended to divide these communities, the story has become a piece of contested cultural property. As part of a limited and shared cultural repertoire that is used to construct identity and produce locality, the story's use by community members, like certain linguistic and weaving activities, serves to establish the right to economic and social opportunities. The changing global economy may contribute to internal and new social divisions, but in the case of the residents of San Antonio and Santa Catarina, it is difficult for tourists and other outsiders to identify differences among the residents and even the towns themselves. For example, handicrafts vendors from Santa Catarina were put off when they found postcards in Antigua boutiques that identified persons from Santa Catarina as Antonecos. Many tourists disembarking from buses coming from San Antonio and Santa Catarina only report visiting San Antonio, when I knew that they had visited people in Santa Catarina.

\section{CONCLUSIONS}

By outlining how the residents of San Antonio and Santa Catarina have been incorporated into tourism and development, I have shown some of the contexts in which the origin story is used. More importantly, its use in these contexts illustrates - to paraphrase Watanabe (1990)-how members of a community survive in a particular place. Surviving in both towns involves contending with religious and economic changes resulting from Protestant missionization, tourism, 
and development. Many people throughout Guatemala - and indeed the worldare part of such transnational movements (Appadurai 1996; Inda and Rosaldo 2001). Instead of looking at the movements of people, ideas, and things, I have sought to examine the ways in which people who have not moved to other places nonetheless do contend with these processes.

It is important to recognize that-although place is irreducible for Mayas (Watanabe 1990) - they are inscribed in that place, physically and ideologically, through their daily practices. Place matters to Mayas like those in San Antonio and Santa Catarina. At the same time, place matters to the Guatemalan government, tourism companies, and development agencies. Because these national and international entities change how Antonecos and Catarinecos conceive of ethnic identity and community rights to certain stories, artifacts, and practices, it is useful to link Watanabe's theories to those of Appadurai. In order for the townspeople to exploit what these national and international entities offer, they must demonstrate need, authenticity, and difference-distinctive Mayaness.

In the past, the origin story was used in both towns by families and leaders to help them remember select aspects of their past and to relate to each other regionally. Now, it has also become crucial to the ways in which they locate themselves within the Guatemalan state and the globe for economic reasons. Although missionaries, tourists, and development workers have mapped specific ethnic identity traits to specific towns, townspeople in San Antonio and Santa Catarina struggle to construct their respective localities and identities through the possession and control of cultural markers that have been historically a part of both communities. The long-term effect could result in the construction of greater difference, further dividing the two towns, as residents seek to commoditize even more cultural practices.

\section{NOTES}

1. The research that informs this article was generously supported by a 1997-1998 U.S. Fulbright IIE Grant, Wenner-Gren Foundation Grant \#6131, and two U.S. Department of Education Title IV Fellowships (Foreign Language and Area Studies) to study Kaqchikel Maya, 1994 and 1996. It was presented in two different forms at the American Society for Ethnohistory Annual Meeting, Minneapolis, November 12-15, 1998, and at the Department of Anthropology, University of Oklahoma, Norman, March 13, 2001. General comments and criticisms at both of these forums helped me improve this article. John Watanabe, Mahir Saul, Alejandro Lugo, Edward Bruner, June Nash, Joseph Whitecotton, Judith Maxwell, David Carey, Jr., and Jennifer Burrell offered constructive criticism on earlier drafts. The final draft benefitted from the generous comments of the editor, Lawrence Straus, and from the manuscript reviewers. Christopher Lutz's close reading of the final drafts and his suggestions for improvement were especially helpful. I am especially grateful to the families of Ixey, Tojil, and Aleandro, as well as other residents of San Antonio Aguas Calientes and Santa Catarina Barahona for sharing their lives with me. This article was prepared while I was a visiting assistant professor in the Department of Anthropology, DePaul University, and Co-Director of the Oxlajuj Aj Kaqchikel Language Program, Tulane University/ Antigua, Guatemala. 
2. Over the past decade, clothing, types of food, and dialectical differences in the Kaqchikel Maya language are also sources of debate between residents of these two towns.

3. My introduction to these towns was as a tourist in 1987. By the time I conducted extensive anthropological fieldwork in San Antonio and Santa Catarina from June 1996 to August 1998, I had completed one earlier fieldwork season in the summer of 1992. I also studied Kaqchikel Maya with Oxlajuj Aj during the summers of 1994 and 1995, while initiating research on the handicrafts market in Antigua. The earlier periods of language study and research helped me develop rapport with residents of both towns. A teacher from each town taught in the Oxlajuj Aj program, a fact which gave me an excuse to visit. As my language skills improved and I won research grants, handicrafts vendors from both towns decided that I was important enough to include in their social and economic lives. My dissertation (Little 2001) explains in greater detail my methods for studying vendors who were in competition with one another.

4. Mo'soi', plural for mo's, is a Kaqchikel word (and also a K'iche' word, but with some different connotations) that means Ladino, foreigner, or stranger, depending on the context in which it is used. When used to refer to another Maya, it is an insult.

5. In Guatemala, as well as other parts of Latin America, indigenous people were gathered into Spanish-controlled settlements in order to better exploit their labor (see Sherman 1979).

6. Maya activists/scholars, such as Demetrio Cojtí Cuxil (1997), Raxche' (1995), and others, envision a Guatemalan nation-state that, in part, begins with local, Maya concepts of identity and community. Their perspectives and those of other Maya activists are described in Fischer and Brown (1996) and Warren (1998).

7. As described in Lutz (1996, 1994), milpas del valle were indigenous agricultural settlements that were granted to individual Spaniards in the early colonial period and that provided tribute in various forms to the Spanish Crown, as well as labor and agricultural produce for Santiago de Guatemala (La Antigua). The working conditions and abuses on the milpas described in a collection of memorias, or reports to Spanish authorities (Lutz and Dakin 1996), were horrendous. It is interesting to note that among the milpas surrounding Antigua, that of Juan de Chávez, which is now San Antonio Aguas Calientes, converted from Spanish control and ownership to indigenous control and ownership after 1550. According to Lutz (1996:xxiii-xxiv and n. 25), San Antonio "was a notable exception." Most other milpas continued the payment of a land-use tax paid on a per capita (tributary) basis to the owner of the milpa's lands, to Spanish vecinos (inhabitants), and, over time, to different religious institutions in Spanish-governed Antigua.

8. This perspective is not limited to present and former residents of San Antonio. A group of K'iche' vendors explained that Rigoberta Menchú was a Maya and that she was an Indigena. However, they did not consider her a K'iche' anymore because she had lived so many years away from San Miguel Uspantán.

9. The contemporary spelling by literate Mayas is su't. However, the word has been alternatively spelled by scholars as tzut (Annis 1987) and tzute (Altman and West 1992).

10. According to Annis (1987:109), the huipil expresses "the fusion of self and community" for Catholics, while it is just a form of self-expression for Protestants. Whereas a huipil produced by a Catholic weaver serves as a form of capital, which has value within the community, the huipil produced by the Protestant weaver is a form of capital, which is convertible to money. Today, such distinctions are not made by Protestants and Catholics. Catholics weave huipiles for money and Protestants wear them to show their connections to the community. 
11. Residents easily recognize differences in weaving designs and colors that typify each respective town's huipiles, just as they recognize subtle linguistic variation and differences in commonly prepared dishes, such as to' $m$, made of corn flour and refried black beans.

12. In each case, INGUAT refused to endorse the vendors. The vendors were not representing just self-interests but were representatives of larger collectives.

13. See Annis (1988) for a summary of the problems that affected San Antonio at the height of the violence in Guatemala.

\section{REFERENCES CITED}

Altman, P. B., and C. D. West. 1992. Threads of identity: Maya costume of the 1960s in Highland Guatemala. Los Angeles: University of California, Fowler Museum of Cultural History.

Annis, S. 1987. God and production in a Guatemalan town. Austin: University of Texas Press.

- 1988. "Story from a peaceful town: San Antonio Aguas Calientes," in Harvest of violence. Edited by R. Carmack, pp. 155-73. Norman: University of Oklahoma Press.

Appadurai, A. 1986. "Introduction: Commodities and the politics of value," in The social life of things: Commodities in cultural perspective. Edited by A. Appadurai, pp. 3-63. Cambridge, Eng.: Cambridge University Press.

- 1996. Modernity at large: Cultural dimensions of globalization. Minneapolis: University of Minnesota Press.

1998. Dead certainty: Ethnic violence in the era of globalization. Public Culture 10:225-48.

Brown, R. 1998. "Case study two: San Antonio Aguas Calientes and the Quinizilapa Valley," in The life of our language: Kaqchikel Maya maintenance, shift, and revitalization. Edited and written by Susan Garzon, R. McKenna Brown, Julia Becker Richards, and Wuqu' Ajpub' (Arnulfo Simón), pp. 101-28. Austin: University of Texas Press.

Carey, David Jr. 2001. Our elders teach us: Maya-Kaqchikel historical perspectives (Xkib' $i j$ Kan Qate' Qatata'). Tuscaloosa: University of Alabama Press.

Cohen, E. 1988. Authenticity and commoditization in tourism. Annals of Tourism Research 15:371-86.

Cojtí Cuxil, D. 1997. Ri Maya' Moloj pa Iximulew: El movimiento Maya (en Guatemala). Guatemala: Editorial Cholsamaj.

de Certeau, M. 1984. The practice of everyday life. Berkeley: University of California Press.

Fischer, E. F., and Brown, M. R., eds. 1996. Maya cultural activism in Guatemala. Austin: University of Texas Press.

FNUAP (Fondo de Población de Naciones Unidas). 1997. La población desarraigada en Guatemala: Cifras actualizadas y situación socioeconomica. Guatemala: FNUAP.

Garrard-Burnett, V. 1998. Protestantism in Guatemala: Living in the New Jerusalem. Austin: University of Texas Press.

Graburn, N. 1976. Ethnic and tourist arts: Cultural expression from the fourth world. Berkeley: University of California.

Inda, J. X., and R. Rosaldo. 2001. The anthropology of globalization: A reader. Oxford: Blackwell.

INE (Instituto Nacional de Estadistica). 1996. X censo nacional de población y $V$ de habitación, 1994. Guatemala: INE. 
INI (Instituto Indigenista Nacional). 1948. San Antonio Aguas Calientes: Sintesis socioeconomica de una comunidad indígena guatemalteca. Publicaciones especiales del Instituto Indigenista Nacional, no. 6. Guatemala: Ministerio de Educación Publica.

Little, W. 2000. Home as a place of exhibition and performance: Mayan household transformations in Guatemala. Ethnology 39:163-81

- 2001. Transnational market and community: The social relations of Kaqchikel Maya vendors. Ph.D. diss., University of Illinois at Urbana-Champaign.

Lutz, C. 1994. Santiago de Guatemala, 1541-1773: City, caste, and the colonial experience. Norman: University of Oklahoma Press.

- 1996. "Introducción y notas históricas," in Nuestro pesar nuestro aflicción: Memorias en lengua Náhuatl enviadas a Felipe II por indígenas del valle de GuatemalaHhacia 1572. Edited by C. Lutz and K. Dakin, pp. xi-xlvii. Mexico: UNAM/CIRMA.

Lutz, C., and K. Dakin. 1996. Nuestro pesar nuestro aflicció: Memorias en lengua Náhuatl enviadas a Felipe II por Indígenas del valle de Guatemala Hacia 1572. Mexico: UNAM/CIRMA.

MacCannell, D. 1992. Empty meeting grounds: The tourist papers. London: Routledge.

Marx, K. 1970. A contribution to the critique of political economy. New York: International Publishers.

Oria, A. 1989. Las relaciones de poder de las cofradias de San Antonio Aguas Calientes del departamento de Sacatepequez. Unpublished Licenciado thesis, Universidad de San Carlos de Guatemala.

Raxche' (Rodríguez Guaján, D.). 1995. Las ONGs y las relaciones interétnicas. Guatemala: Editorial Cholsamaj.

Sherman, William L. 1979. Forced native labor in sixteenth-century Central America. Lincoln: University of Nebraska Press.

Stoll, D. 1982. Fishers of men or founders of empire? The Wycliffe Bible translators in Latin America. London: Zed Press.

Warren, K. 1989. The symbolism of subordination: Indian identity in a Guatemalan town. Austin: University of Texas Press.

- 1998. Indigenous movements and their critics: Pan-Maya activism in Guatemala. Princeton, N.J.: Princeton University Press.

Watanabe, J.. 1990. "Enduring yet ineffable community in the western periphery of Guatemala," in Guatemalan Indians and the state, 1540 to 1988. Edited by C. Smith with M. Moors, pp. 183-204. Austin: University of Texas Press.

-1992. Maya saints and souls in a changing world. Austin: University of Texas Press.

Whatmore, M., and P. Eltringham. 1990. Guatemala and Belize: The rough guide. London: Rough Guides. 